\title{
Gauging differential health among the sexes at Windover (8Br246) using the Western Hemisphere Health Index
}

\author{
Rachel K Wentz/ ${ }^{+}$, Bryan Tucker*, John Krigbaum*, Glen H Doran \\ Department of Anthropology, Florida State University, Tallahassee, FL 32306, US \\ **Department of Anthropology, University of Florida, FL, US
}

\begin{abstract}
Assessment of intrapopulation human health provides information concerning social structure, division of labor, and lifestyle. Differential health among the sexes can provide clues to social roles, resource acquisition and status within prehistoric populations. Windover (8Br246) is an Archaic mortuary pond located in eastern central Florida. Its occupation spans over 500 years and dates to 7000 years BP. Over 168 well-preserved individuals were excavated, providing a glimpse into life during Florida's Archaic. Through the application of the Western Hemisphere Health Index, we find that males within the group experienced better overall health than females. Males outscore females in quality of life, percent of maximum scores, stature, anemia, dental disease, and infection. $\mathrm{Fe}$ males out-score males in enamel hypoplasia and degenerative joint disease. Causative factors for observed differential health are examined and include activity levels, sexual division of labor, access to resources, and the physiological demands of childbearing.
\end{abstract}

Key words: paleoepidemiology - archaic - health index - disease sex ratio - stress indicators - prehistory

Bioarchaeological studies among prehistoric human populations allow the effects of geographic location, social structure, and subsistence strategies to be assessed with respect to overall health. Examinations within populations permit factors that contribute to differential health among subgroups of a population to be discerned as well as potential causative factors identified. Potential causative factors include variations in status and its affect on differential resource acquisition, social taboos that place dietary limitations on select groups within a population, and physiological challenges associated with childbearing.

There have been an increasing number of studies that examine differential health among the sexes (Haviland 1967, Holden \& Mace 1999, Sofaer Derevenski 2000, Slaus 2000, Prowse et al. 2005). This research was part of a dissertation project that examined the health of an Archaic population from Florida through the application of the Western Hemisphere Health Index (Steckel \& Rose 2002). The examination of differential health among the sexes was an attempt to discern physical and social factors affecting overall health among a hunter/gatherer population from Florida's Archaic.

\section{MATERIALS AND METHODS}

The Windover site, a charnel pond located in the eastcentral Florida coastal area near present-day Titusville, was discovered in 1982 during construction within the Windover Farms suburban housing development. Charnel, or mortuary ponds consist of shallow ponds underlain by intact peat sediments into which burials were placed

${ }^{+}$Corresponding author: bones1012@hotmail.com Received 20 July 2006

Accpted 16 October 2006 during the Early and Middle Archaic times (Doran 2002). Similar sites have been discovered throughout Central and South Florida. The mean of nine radiocarbon dates on human bone, wooden stakes, and remains of a bottle gourd is 7442 radiocarbon years BP (uncorrected), making Windover the largest sample of its antiquity in North America (Doran \& Dickel 1988).

The remains of over 168 individuals were excavated. The population consists of an approximately equal ratio of males to females, a diverse population profile with ages ranging from infant to $65+$ years, and the exceptionally preserved remains of a large number of sub-adults comprising approximately half $(52 \%)$ of the sample (Stojanowski et al. 2002). The state of preservation at Windover has permitted cellular and molecular analyses, including the first sequence of a nuclear gene from ancient human remains (Tuross et al. 1994). Windover provides a rare glimpse into the lifestyle of the people of Florida's Archaic and facilitates a bioarchaeological approach to population studies.

The Western Hemisphere Health Index (Steckel \& Rose 2002) was developed to evaluate health over broad geographic areas and temporal periods. Organized in the late 1980s by Richard Steckel and Jerome Rose, the project brought together a multidisciplinary team of physical anthropologists, demographers, and economic and medical historians to devise an approach to evaluating the history of health in the Western Hemisphere using data from human skeletal remains from archaeological contexts.

The database compiles data from 218 archaeological sites and 12,520 skeletons located in North, Central, and South America. The sites were combined based on chronological and ecological similarity, for a total of 65 sites. Eighty percent of the individuals are Native American, with Euro-Americans and African-Americans accounting for equal percentages of the remaining $20 \%$. The temporal distribution includes individuals dating from 7000 years $\mathrm{BP}$ to the early XX century. Of the Native Americans, $11.9 \%$ 
are from Central America, 22\% are from South America, and the remainder from North America.

The health index utilizes two components: length of life and quality of life. Because of the problems inherent in estimating life expectancy from skeletal populations, quality of life is emphasized and gauged based on the assessment of seven skeletal indicators of health (see Steckel \& Rose 2002 for complete protocol and methodology, or http://global.sbs.ohio-state.edu/project_overview. $\mathrm{htm})$. The indicators include stature and robusticity, infection, dental health, enamel hypoplasias, trauma, degenerative joint disease, and cribra orbitalia/porotic hyperostosis. The number of person years lived is computed based on number and age of individuals within the population. Individuals are scored for each category, with scores ranging from zero to $100 \%$ based on presence, absence or degree of pathology. For example, an individual with no signs of trauma would receive a score of $100 \%$ for that category. Raw scores for each individual are aggregated to produce a "population score". The overall score is presented as a "percent of the maximum" $(100 \%)$ as well as the "maximum quality life years lived". "Maximum quality life years lived" is out of a total of 26.38 years, based on Model West life tables for prehistoric populations. The further this score deviates from 26.38 years, the higher the incidence of biological stress within the population. In addition to the two main scores, scores are also presented for each skeletal indicator.

\section{RESULTS}

Scores within the index are typically not calculated based on sex due to inadequate sample sizes of males and females within many sites. Windover, however, had adequate representation of each sex ( 35 females, 43 males) to accommodate such calculations. Table I, presents overall health scores for the Windover population and separate scores for males and females.
Males had higher overall scores than females in six out of nine categories, indicating lower incidences of these types of pathological conditions. Males out-scored females in overall quality of life, percent of maximum scores, stature, anemia, dental disease, and infection. Males also had overall higher number of person years for the index, but this could be due to the larger sample of males within the population (43 males vs 35 females). Females outscored males in enamel hypoplasia and degenerative joint disease. Fig. 1, provides skeletal indicator scores for males and females.

Trauma scores were slightly lower among males (a difference of $4.1 \%$ ), reflecting higher incidences of traumatic injury compared to females. In a previous analysis of fracture frequencies among the people from Windover (unpublished observations) involving a larger sample size from the population, males and females exhibited similar numbers of fractures, with the majority of injuries being accidental in nature. Neither sex exhibited fracture patterns indicative of interpersonal conflict, such as multiple injuries in combination with fractures of the face or head. Although fractures of the ulna were frequent (15 total) and parry fractures have been linked to interpersonal conflict (Ortner \& Putschar 1981, •ivanoviæ 1982, Larsen 1997 , Byers 2002), none of the individuals displayed patterned injuries suggesting intentional injury. The higher incidence of traumatic injury among the males at Windover could merely reflect higher levels of activity, such as increased travel distances and hazards associated with food procurement. Fracture frequencies (number of fractures per number of observable elements) and percentage of each element fractured are provided in Table II.

Arm trauma prevailed as the most common form of injury, predominantly as ulnar fractures. Although Windover females show slightly higher incidences, an earlier study indicated they were the result of accidental injury, not related to interpersonal violence (unpublished



Fig. 1: skeletal indicator scores for Windover males and females.

TABLE I

Health scores among males and females from Windover

\begin{tabular}{lcccccccccc}
\hline Group & Qual & \% of max & Stature & Hyp. & Anem. & Dent. & Infec. & DJD & Trauma & Pers. Years \\
\hline Total population & 18.05 & 68.4 & 24.5 & 39.5 & 85.2 & 89.4 & 77.5 & 87.0 & 76.0 & 13457 \\
Males & 18.16 & 66.8 & 26.1 & 37.3 & 94.3 & 89.8 & 82.7 & 85.5 & 69.7 & 6675 \\
Females & 17.24 & 65.4 & 23.5 & 40.0 & 76.3 & 87.0 & 66.5 & 90.3 & 73.8 & 4716 \\
\hline
\end{tabular}




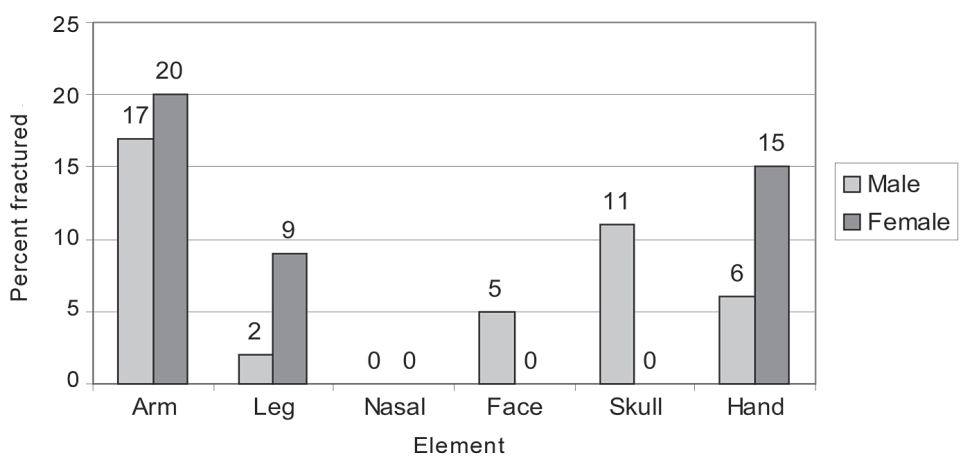

Fig. 2: percents of elements fractured among Windover males and females.

TABLE II

Fracture frequencies and percentages for males and females from Windover (frequencies are provided as number of fractures/elements observed)

\begin{tabular}{lcccccc}
\hline & Arm & Leg & Nasal & Face & Skull & Hand \\
\hline Male & $7 / 40$ & $1 / 40$ & $0 / 2$ & $1 / 1$ & $3 / 27$ & $2 / 32$ \\
& $17 \%$ & $2 \%$ & $20 \%$ & $85 \%$ & $0 \%$ & $11 \%$ \\
Female & $6 / 30$ & $3 / 33$ & $0 / 14$ & $0 / 11$ & $0 / 28$ & $4 / 26$ \\
& $20 \%$ & $9 \%$ & $0 \%$ & $0 \%$ & $0 \%$ & $15 \%$ \\
\hline
\end{tabular}

observation). Females lacked fractures of the face and skull yet had significantly more trauma to the bones of the hands. Molleson (1994) linked traumatic alteration of toe joints among the females of Abu Hureya to physical demands associated with grinding grain while kneeling. The high rate of hand fractures among the females of Windover could possible be associated with the processing of hides or plant foods, work traditionally delegated to females. Textiles recovered with many of the burials may have also been the result of female-designated labor (Andrews et al. 2002).

High rates of facial and skull trauma have been linked to interpersonal conflict, yet the males from Windover lacked associated evidence of such conflict (unpublished observation). Overall trauma scores for the Windover population were significantly lower compared to the rest of the WHHI dataset (Windover trauma score of 76.0 compared to total dataset mean of 85.5). Exceptional preservation could account for the elevated number of documented fractures. Yet the low scores attest to the physical chal- lenges inherent to Florida's Archaic period.

Degenerative joint disease scores were high for both sexes, compared to the rest of the populations within the database (Windover males 85.5, females 90.3; total dataset mean score of 79.00; total dataset median score of 79.85). Males had a slightly lower score, which could be indicative of greater activity levels, as reflected in trauma scores as well. The ratios of joints affected by DJD compared to the number of joints observed, as well as the percentage of joints affected are provided in Table III.

The highest rates of degenerative joint disease, among both sexes, affected the vertebrae. In reviewing relatively modern vertebral columns, Nathan (1962) found that by the third decade of life a large proportion of individuals studied had vertebral osteophytosis, which are early stages of degenerative joint disease; by the fifth decade all of them had the condition (Roberts \& Manchester 1995). The higher rates of DJD affecting shoulders and elbows among the females could, like the increased rates of traumatic injury to the hands, be related to repeated

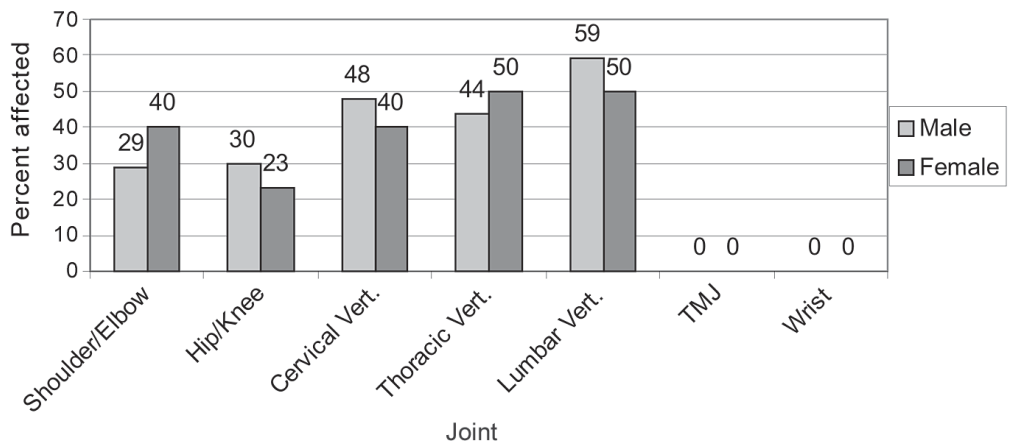

Fig. 3: percentage of joints affected by degenerative joint disease among Windover males and females. 
TABLE III

Ratios of joints affected and percentage involvement of males and females from Windover (ratios are provided as number of joints affected/joints observed)

\begin{tabular}{lccccccc}
\hline & Shoulder/Elbow & Hip/Knee & CervicalVert. & ThoracicVert. & LumbarVert. & TMJ & Wrist \\
\hline Male & $12 / 41$ & $12 / 40$ & $17 / 35$ & $13 / 29$ & $19 / 32$ & $0 / 26$ & $0 / 36$ \\
& $29 \%$ & $30 \%$ & $48 \%$ & $44 \%$ & $59 \%$ & $0 \%$ & $0 \%$ \\
Female & $12 / 30$ & $6 / 26$ & $9 / 22$ & $10 / 20$ & $9 / 18$ & $0 / 26$ & $2 / 25$ \\
& $40 \%$ & $23 \%$ & $40 \%$ & $50 \%$ & $50 \%$ & $0 \%$ & $8 \%$ \\
\hline
\end{tabular}

stress associated with food and hide processing. The lack of DJD affecting the wrists of females is curious when considering activity related bone changes. The higher rates of hip and knee DJD among males could be indicative of increased walking associated with hunting activities.

Hypoplasia scores were similar, yet slightly higher in females. Since hypoplastic defects can reflect nutritional status, pathogen load, and metabolic disruptions (MoggiCecchi et. al 1994), this score suggests that males and females experienced similar levels of general health and nutrition during developmental years. Other dental scores reveal discrepancies in health among males and females. Males had a lower incidence of caries $(4.5 \%$ of teeth affected vs $6.9 \%$ in females), yet had higher numbers of abscesses (4.3\% rate vs. $3.2 \%$ rate in females) and higher levels of antermortem tooth loss (10.5\% of teeth lost antemortem vs. $7.9 \%$ lost in females). Breakdowns of dental scores are provided in Tables IV.

Stature scores were higher among males (mean/median of 164 in males vs. mean/median of 150 in females). This suggests that males may have had access to better diets than females and experienced lower rates of infectious disease and anemia, resulting in greater overall height. Kemkes-Grottenthaler (2005) found correlations between stature and longevity among 2,923 skeletons, with males and females displaying significant inverse relationships between adult height and age at death. Among the Windover population, the oldest males were the tallest (Fig. 4). There appears no trend among females.

Haviland (1967) attributed marked sexual dimorphism in stature partially to genetics but also as a reflection of the relatively lower status for women in Maya society. Holden and Mace (1999) found correlations with stature and contribution to subsistence. Female stature from

\section{TABLE IV}

Dental pathology among Windover males and females

\begin{tabular}{lcc}
\hline & Males & Females \\
\hline Total number of teeth examined & 930 & 759 \\
Total number of sockets examines & 768 & 1093 \\
Number of teeth with carious lesions & 42 & 53 \\
Percent of teeth affected by carious lesions & 4.5 & 6.9 \\
Total number of abscesses & 48 & 29 \\
Percent of sockets affected by abscess & 4.3 & 3.2 \\
Total number of teeth lost premortem & 115 & 71 \\
Percent of teeth lost premortem & 10.5 & 7.9 \\
\hline
\end{tabular}

populations around the world was assessed in order to determine whether sexual dimorphism is related to the roles each sex plays in food procurement. They found that sexual dimorphism in stature was negatively associated with women's contribution to subsistence, with greater overall female height associated with societies where women contribute more to food production. This is probably due to better overall nutrition among females from such groups with better access to quality foods. Better overall stature among males may have contributed to greater number of person years among the males from Windover. Stature distributions for males and females are provided in Fig. 5.

Scores for anemia and infectious disease were significantly lower among females, indicating higher rates of biological stress compared to males. Sullivan (2005) found higher rates of anemia among females interred at the Me-

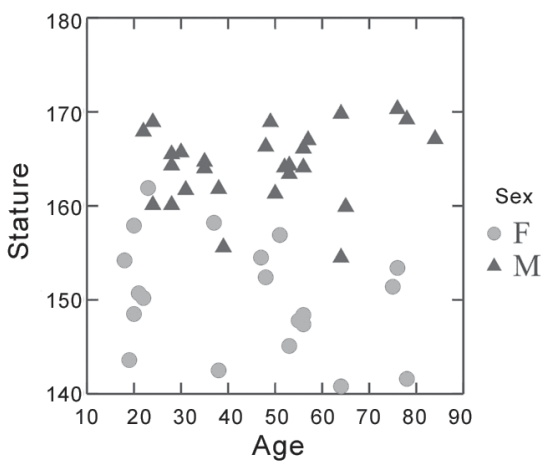

Fig. 4: stature and age distributions for Windover males and females.

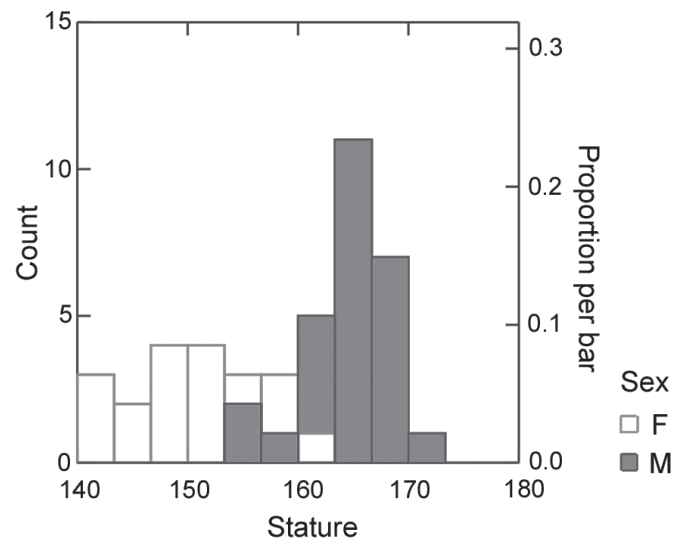

Fig. 5: stature distributions for Windover males and females. 
dieval Gilbertine Priory in York, England, which she associated with chronic anemia from high iron demand reproductive functions. Historic accounts (Engelbrecht 1987) note the intensive labor demands among Iroquois women, which included carrying heavy loads, processing foods, and caring for family. Sofaer Derevenski (2000) noted differential patterns in degenerative joint disease among the sexes at XIV-XIX century sites. At Ensay and the medieval site of Wharram Percy, both in the UK, females exhibited distinct osseous changes due to load bearing of the spine associated with carrying baskets. Slaus (2000) attributed higher frequencies of hypoplasias among females within the Late Medieval population of Nova Raca, Croatia to higher levels of biological stress compared to males. He also attributed significant sex differences among dental pathology to differential access to resources. Table IV provides incidences of cribra orbitalia and infection of the tibia and remainder skeleton for males and females.

Females had significantly higher rates of cribra orbitalia and porotic hyperostosis, both indicators of periods of biological stress. The rates of tibial infection were also

\section{TABLE V}

Incidences of cribra orbitalia, porotic hyperostosis, and periostitis among Windover males and females

\begin{tabular}{|c|c|c|}
\hline & Males & Females \\
\hline $\begin{array}{l}\text { Orbits with cribra orbitalia/ } \\
\text { orbits observed }\end{array}$ & $5 / 29$ & $8 / 29$ \\
\hline Percent of orbits with cribra orbitalia & 17 & 27 \\
\hline $\begin{array}{l}\text { Crania with porotic hyperostosis/ } \\
\text { number of crania observed }\end{array}$ & $2 / 32$ & $3 / 30$ \\
\hline Percent of crania with porotic hyperostosis & 6 & 10 \\
\hline $\begin{array}{l}\text { Tibia with periostitis/ } \\
\text { number of tibia examined }\end{array}$ & $2 / 39$ & $3 / 32$ \\
\hline Percent of tibia with periostitis & 5 & 9 \\
\hline $\begin{array}{l}\text { Other postcranial bones with periostitis/ } \\
\text { bones observed }\end{array}$ & $6 / 42$ & $5 / 35$ \\
\hline $\begin{array}{l}\text { Percent of other postcranial bones } \\
\text { with periostitis }\end{array}$ & 14 & 14 \\
\hline
\end{tabular}

higher among females, although skeletal infection was equal among the sexes.

To evaluate whether variation in diet contributed to health discrepancy among the sexes at Windover, stable isotope analyses were conducted. The mineral (hydroxyapatite) portion of bone from 20 individuals (10 males, 10 females) from Windover was assayed for $\delta^{13} \mathrm{C}$ and $\delta^{18} \mathrm{O}$ ratios. The organic (collagen) portion of bone was not sampled due to complexities involved in removing a preservative, Rhoplex, from the samples (Tuross et al. 1994).

Carbon isotopes in terrestrial systems vary by photosynthetic pathway: $\mathrm{C}_{3}, \mathrm{C}_{4}$, and CAM. $\mathrm{C}_{3}$ plants have $\delta^{13} \mathrm{C}$ ratios from -35 to $-20 \%$ and $\mathrm{C}_{4}$ plants have $\delta^{13} \mathrm{C}$ values that range from -15 to $-7 \%$ (Smith \& Epstein 1971, Smith 1972). CAM plants have $\delta^{13} \mathrm{C}$ values that overlap with $\mathrm{C}_{3}$ and $\mathrm{C}_{4}$ plants. Generally, CAM plants are not a substantial concern in the Eastern Woodlands, though prickly pear (a CAM plant) does grow along the eastern coast and has been identified at Archaic sites including Windover (Newsom 1994, Tuross et al. 1994, Doran 2002). Carbon isotopes also differ between terrestrial and marine systems. Marine vertebrates typically have $\delta^{13} \mathrm{C}$ values of -19 to $-9 \%$ compared to the -35 to $-20 \%$ range of $\mathrm{C}_{3}$ plants (Smith 1972, Schoeninger \& DeNiro 1984).

Oxygen isotopes track temperature, precipitation, and evapotransportation. The $\delta^{18} \mathrm{O}$ of precipitation is largely determined by the ambient temperature and amount of precipitation. Broadly similar regions have similar seasonal $\delta^{18} \mathrm{O}$ averages, which differ in a predictable fashion by latitude, altitude, and distance from the sea. As a result $\delta^{18} \mathrm{O}$ values are successfully employed in studies of migration and immigration in archaeological contexts (e.g. White et al. 1998, Montgomery et al. 2005, Turner et al. 2005).

Results of the analyses show no significant differences in diet or area of residence between males and females (Figs 7-9). The sample contained no "extralocal" individuals based on $\delta^{18} \mathrm{O}$ values, nor did the $\delta^{13} \mathrm{C}$ values show any significant difference in bulk diet between the sexes. However, three females and one male clustered apart from the other 16 individuals based on their $\delta^{13} \mathrm{C}$ values (Fig. 9). The differences in diet between the majority of the population and these four individuals may be culturally induced or may represent changes in dietary patterns over the long (ca 1000 year) use of the site.



Fig. 6: percentage affected by anemia and infectious lesions among Windover males and females. 


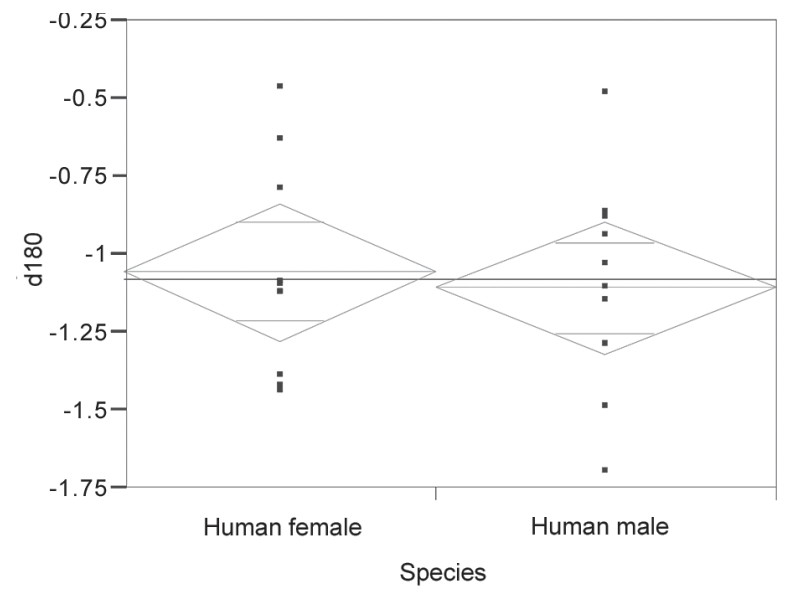

Fig. 7: D180 values for Windover males and females.

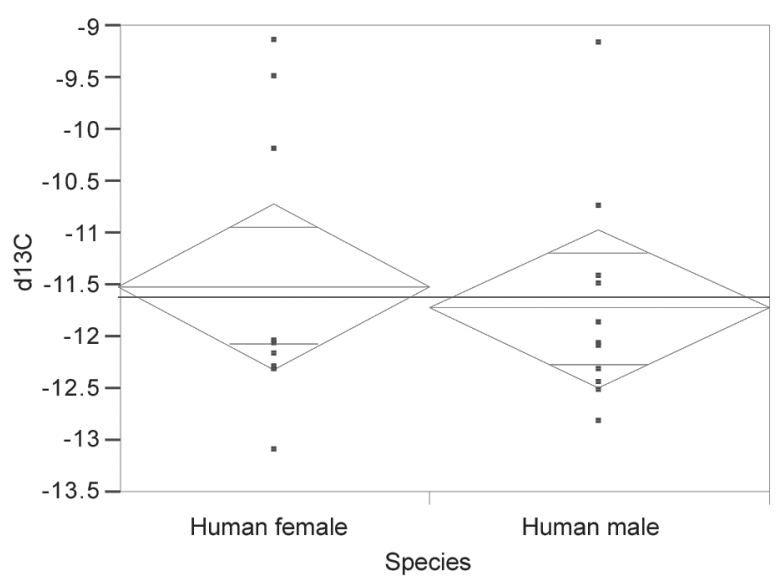

Fig. 8: D13C values for Windover males and females.



Fig. 9: scatterplot of $\mathrm{d} 13 \mathrm{C}$ and $\mathrm{d} 18 \mathrm{O}$ values for Windover males and females.

\section{DISCUSSION}

Rosenberg (1980) documented numerous ethnographic accounts that attest to differences among the sexes regarding access to food. Among Old and New World hunter/gatherer populations, male-female dietary discrepancies account for lower life expectancy in females due to limited access to meat (women are traditionally allowed to eat only after males) and food-related taboos that put nutritional limitations on their diets. Higher rates of stress among females from Windover could be linked to diets lacking adequate amounts of protein, diminished resistance to pathogens, as well as the metabolic demands associated with child bearing.

The disparity in scores between the sexes could be indicative of unequal access to resources. If males were given preferential access to higher quality food sources, such as protein, they would be less prone to iron deficiency anemia, therefore exhibiting higher overall scores than females. Prowse et al. (2005) found that females among the Roman population of Isola Sacra, Italy between the I and III enturies AD exhibited lower isotopic levels of carbon and nitrogen suggesting, as a whole, they had less access to isotopically enriched marine foods, which are also seen historically to have been higher-status nutrients. However, the stable isotope analyses of the Windover remains showed no differentiation in diet between the sexes. Whether they had access to equal amounts of these foods is unknown. Slaus (2000) noted reduced life expectancy among females in medieval Croatia due to elevated levels of biological stress during life, as indicated by skeletal pathology. Better nutrition would have afforded the males at Windover increased resistance to infectious disease, as indicated by higher infection scores. Stature, infection, dental and anemia scores all attest to better overall health of Windover males over females. The disparity in health scores may reflect the demands of the hunter/gatherer lifestyle in combination with the metabolic challenges of childbearing during Florida's Archaic.

\section{REFERENCES}

Andrews RL, Adovasio JM, Humphrey B, Hyland DC, Gardner JS, Harding DG, Illingworth JS, Strong DE 2002. Conservation and analysis of textile and related perishable artifacts. In GH Doran, Windover: Multidisciplinary Investigations of an Early Archaic Florida Cemetery, University Press of Florida, Gainesville.

Byers SN 2002. Introduction to Forensic Anthropology, Allyn and Bacon, Boston

Doran GH. 2002. Windover: Multidisciplinary Investigations of an Early Archaic Florida Cemetery, University Press of Florida, Gainesville.

Doran GH, Dickel DN 1988. Multidisciplinary investigations at the Windover site. In BA Purdy, Wet Site Archaeology, Telford Press, Caldwell, p. 263-289.

Engelbrecht W 1987. Factors maintaining low population density among the prehistoric New York Iroquois. Am Ant 52: 13-27.

Haviland WA 1967. Stature at Tikal, Guatemala: implications for ancient Maya demography and social organization. Am 
Anthropol 32: 316-325.

Holden C, Mace R 1999. Sexual dimorphism in stature and women's work: a phylogenetic cross-cultural analysis. $A m \mathrm{~J}$ Phys Anthropol 110: 27-45.

Kemkes-Grotttenthaler A 2005. The short die young: the interrelationship between stature and longevity - evidence from skeletal remains. Am J Phys Anthropol 128: 340-347.

Larsen CS 1997. Bioarchaeology: Interpreting Behavior from the Human Skeleton, Cambridge University Press, Cambridge.

Moggi-Cecchi J, Pacciani E, Pinto-Cisternas J 1994. Enamel hypoplasia and age at weaning in 19th century Florence, Italy. Am J Phys Anthropol 93: 299-306.

Molleson T 1994. The eloquent bones of Abu Hureya. Sci Am p. 60-65.

Montgomery J, Evans JA, Powlesland D, Roberts CA 2005. Continuity or colonization in Anglo-Saxon England? Isotope evidence for mobility, subsistence practice, and status at West Heslerton. Am J Phys Anthropol 126:123-138.

Nathan H. 1962. Osteophytes of the vertebral column. J Bone Joint Surg 44A:243-268.

Newsom L 1994. Archaeobotanical data from Groves Orange Midden (8VO2601), Volusia County, Florida. Florida Anthropol 47: 404-417.

Ortner DJ, Putschar WGJ 1981. Identification of Pathological Conditions in Human Skeletal Remains, Smithsonian Contributions to Anthropology \#28, Smithsonian Institution, Washington.

Prowse TL, Schwarcz HP, Saunders SR, Macchiarelli R, Bondioli L 2005. Isotopic evidence for age-related variation in diet from Isola Sacra, Italy. Am J Phys Anthropol 128: 213.

Roberts C, Manchester K 1995. The Archaeology of Disease, Cornell University Press, New York.

Rosenberg EM 1980. Demographic effects of sex-differential nutrition. In NW Jerome RF Kandel, GH Pelto (eds), Nutritional Anthropology: Contemporary Approaches to Diet and Culture, Redgrave Publishing Co., Pleasantville, p. 181204.
Schoeninger MJ, Deniro MJ 1984. Nitrogen and carbon isotopic composition of bone-collagen from marine and terrestrial animals. Geochim Cosmochim Acta 48: 625-639.

Slaus M 2000. Biocultural analysis of sex differences in mortality profiles and stress levels in the Late Medieval population from Nova Raca, Croatia. Am J Phys Anthropol 111: 193-209.

Smith BN 1972. Natural abundance of the stable isotopes of carbon in biological systems. BioScience 22: 226-231.

Smith BN, Epstein S 1971. Two categories of 13C/12C ratios for higher plants. Plant Physiol 47: 380-384.

Sofaer Derevenski JR 2000. Sex differences in activity-related osseous change in the spine and the gendered division of labor at Ensay and Wharram Percy, UK. Am J Phys Anthropol 111: 333-354.

Steckel RH, Rose JC 2002. The Backbone of History: Health and Nutrition in the Western Hemisphere, Cambridge University Press, Cambridge.

Stojanowski CM, Seidemann RM, Doran GH 2002. Differential skeletal preservation at Windover pond: causes and consequences. Am J Phys Anthropol 119: 15-26.

Sullivan A 2005. Prevalence and etiology of acquired anemia in Medieval York, England. Am J Phys Anthropol 128: 252272.

Turner BL, Kingston JD, Milanich JT 2005. Isotopic evidence of immigration linked to status during the Weeden Island and Suwannee Valley periods in North Florida. Southeastern Archaeol 24: 121-136.

Tuross N, Fogel ML, Newsom L, Doran GH 1994. Subsistence in the Florida archaic: the stable-isotope and archaeobotanical evidence from the Windover site. Am Ant 59: 288-303.

White CD, Spence MW, Stuart-Williams HLQ, Schwarcz HP 1998. Oxygen isotopes and the indentification of geographical origins: the Valley of Oxaca versus the Valley of Teotihuacan. J Archaeol Sci 25: 643-655.

-ivanoviæ S 1982. Ancient Diseases: The Elements of Palaeopathology, Pica Press, New York. 
